\title{
Prospects for the gene pool use of stone fruit plants in the distant hybridization of cherries
}

\author{
Oksana Eremina*, and Viktor Eremin \\ Krymsk Experiment Breeding Station of VIR, N.I. Vavilov All-Russian Institute of Plant Genetic \\ Resources, 353384, Krymsk, Krasnodar Region, Russia
}

\begin{abstract}
. 18 species of cherries are collected for the preservation and study in the gene pool of the station. The following species $P$. sachalinensis, $P$. kurilensis, $P$. pensylvanica, $P$. incisa, P. serrullata, $P$. lannesiana, $P$. fruticosa separated by economically valuable traits, were involved in distant hybridization as a female parent. Cherry varieties, donors of large - fruited fruit, performed as a male parent. The article shows the yielding results of interspecies crossing, the patterns of inheritance of hybrid traits of early and late emergence from the condition of a deep dormant period and winter hardiness. According to the results of our research, we recommended the following species $-P$. lannesiana, $P$. serrullata, $P$. sachalinensis as donors of short onset, and as for late and long-lasting $-P$. pensylvanica, $P$. incisa, $P$. fruticosa. Species which transmit the sign of winter hardiness to their progeny $-P$. fruticosa, P. incisa and P. kurilensis.
\end{abstract}

\section{Introduction}

Distant hybridization plays an important role in the origin of most fruit cultures and the emergence of their variety [1]. The varieties with a complex of the most valuable features, one of which is stress tolerance, having a decisive role in their distribution in industrial plantings, were developed using distant hybridization.

Sour cherry is not a wild species. It is a hybridogenic species of Prunus fruticosa Pall. $\times$ Prunus avium L. Its origin was proved by the study of isoenzymes by a group of researchers in the United States. In their investigations, using precision, genetic and biotechnological methods, and molecular markers, they revealed the features of genetic interactions and identified some of the main genes of cherries [2]. The inclusion of new wild species in selection helps to create varieties with original features.

In the south of Russia, a new secondary center for the intermutation of fruit cultures has appeared in unusual environmental conditions for them. Hybridogenic forms and especially varieties derived under such conditions from interspecific hybridization are easier to adapt to new conditions which contribute to the emergence of new positive intersections on the most significant features [3].

\footnotetext{
*Corresponding author: eremin-ox@bk.ru
} 
A major reason for the steady decline in cherry fruit output is the frequent damage to the flower buds during overwintering and after dormancy release. In some years, diseases can do a lot of damage to cherries [4].

\section{Materials and methods}

The research was conducted in 2014-2020 at the Krymsk Experiment Breeding Station, Branche of the N.I. Vavilov All-Russian Institute of Plant Genetic Resources. The objects of research were 1927 hybrid seedlings received as a result of interspecific hybridization of 12 crossing combinations. For the assessment of the duration of winter dormancy, the method of Ya. S. Nesterov was used [5]. The study of the winter hardiness of hybrids was conducted in the field as a resistance to the damaging factors of the cold season [6]. Statistical processing of the experimental data was conducted using the methods of deviation from the mean for the variant, the analysis of variance using the SNEDERCOR application software [7,8].

\section{Results and discussion}

Damage and freezing of flower buds significantly restricts the areas of industrial crops of cherry and sour cherry. It does not degrade the growth of the tree, but it deprives it of its production value $[9,10,11]$. In this regard, our attention was drawn to the East Asian cherry species of the genus Prunus L. Wild cherry forms include 18 species in the genetic fund of the Krymsk EBS, which were mostly collected during expeditions to the Far East, mainly in the coastal areas of Primorsky Krai. On the islands of Sakhalin, Kunashir, Iturup, etc. they are highly resistant to low temperatures [12].

Many years of research of economically important traits and their inheritance in hybrid offspring of varieties have identified the genetic and phenotypic potential of the primordial species of sour cherry and cherry $[13,14]$.

In the gene pool focused on the station, genotypes have been identified that provide adaptability to extreme weather conditions and large-scale fruitfulness revealed in the progeny (Table 1).

Table 1. Sources of positive traits of cherry species for cultivation use

(Krymsk EBS, VIR Branch, 1990-2000)

\begin{tabular}{|c|c|c|}
\hline Sign & Plant species & Specimen \\
\hline \multirow{7}{*}{ Winter hardiness } & P. kurilensis & I-1, I-2, DVOS 7-2 \\
\hline & P. incisa & №3, from GDR, №1, №2 \\
\hline & P. lannesiana & №1, №2, Sc №9 \\
\hline & P. fruticosa & BS-2, Luhansk 7 \\
\hline & P. maackii & Vladivostok 4, Vladivostok 17 \\
\hline & P. maximowiczii & Goryachiy Klyuch 1, Lazovskoe №2, 99D \\
\hline & P. mahaleb & Jermuk 30, ANT 11/74, Kamensk 16 \\
\hline \multirow{3}{*}{ Drought tolerance } & P. fruticosa & Luhansk 7, Rodnik 5, Stepnaya 3 \\
\hline & P. maximowiczii & 99D, Ricorda 1, Ricorda 3 \\
\hline & P. mahaleb & Kamensk 16, Geghard \\
\hline \multirow{3}{*}{ Early bloom } & P. sachalinensis & BG-30, №5, X-30, Kunashir 20, Popova 32 \\
\hline & P.pseudocerasus & C 34-4, C 56-12 \\
\hline & P. nipponica & \\
\hline \multirow{4}{*}{ Late bloom } & P. fruticosa & \multirow{4}{*}{ Most forms } \\
\hline & P. maximowiczii & \\
\hline & P. mahaleb & \\
\hline & P. pensylvanica & \\
\hline
\end{tabular}




\begin{tabular}{|c|c|c|}
\hline \multirow{4}{*}{ Poor growth } & P. fruticosa & \multirow{4}{*}{ Most forms } \\
\hline & P.kurilensis & \\
\hline & P. incisa & \\
\hline & P. canescens & \\
\hline \multirow{4}{*}{$\begin{array}{l}\text { Coccomycosis } \\
\text { resistance }\end{array}$} & P. incisa & from GDR, №15 \\
\hline & P. lannesiana & №2, №1 \\
\hline & P. canescens & \\
\hline & P. serrulata & Kwanzan, Royal Burgundy \\
\hline \multirow{3}{*}{$\begin{array}{c}\text { Resistance to } \\
\text { moniliosis }\end{array}$} & P. sachalinensis & Most forms, BG-30, №6 \\
\hline & P. lannesiana & №2, №1 \\
\hline & P. pensylvanica & $1-24-4$ \\
\hline \multirow{5}{*}{$\begin{array}{c}\text { Lack of bitterness } \\
\text { in fruits }\end{array}$} & P. incisa & from GDR \\
\hline & P. sachalinensis & BG -30 \\
\hline & P. lannesiana & №2 Sc-№9 \\
\hline & P. serrulata & №26, №12 \\
\hline & P. pensylvanica & $1-24-4$ \\
\hline \multirow{2}{*}{$\begin{array}{l}\text { Short dormant } \\
\text { period }\end{array}$} & P. nipponica & \\
\hline & P. serrulata & \\
\hline \multirow{4}{*}{$\begin{array}{l}\text { Long dormant } \\
\text { period }\end{array}$} & P. fruticosa & Most forms \\
\hline & P. maximowiczii & Lazovskoe №2, Ricorda 3 \\
\hline & P. mahaleb & Kamensk 16, Geghard, Kamensk 18 \\
\hline & P. pensylvanica & $1-24-4$ \\
\hline
\end{tabular}

Collected and focused on the Krymsk EBS, VIR Branch of the gene pool of fruit plants is undergoing primary study of biology, phenology, morphology, and manufacturability. Thus, the best carriers of selectively significant traits of their determinancy and features of transmission to offspring were distinguished.

Among the types of sour cherries kept at the station, Prunus mahaleb, Prunus maackii, Prunus maximowiczii, Prunus pensylvanica, Prunus fruticosa, and Prunus kurilensis have valuable characteristics - high frost resistance [13].

In order to increase the effectiveness of the selection program, an in-depth study of the sour cherry gene pool, various types of sour cherries, and the selection of gene carriers from it, both donors and sources of economically valuable traits, plays an important role. The most relevant new types of sour cherries for the selection process are intensely involved in the selection process.

Later, donors of selection-valuable traits, which are involved in inter-generic and interspecific hybridization on the Krymsk EBS, are chosen from the sources that have passed practical selection according to the results [15]. In the selective plantings of the station, there are hybrids of cherry varieties created with the participation of these species.

The most successful distant crossings of varieties with species were in favorable weather conditions for the development of female gametophytes during the flowering period in 2012 and 2013.

The following types of sour cherries were involved in hybridization as the female parent. The male parent was chosen as the cherry variety with the established donor sign of large - fruited cherry - Valery Chkalov and Krupnoplodnaya (Table 2).

For all combinations, the average number of four-week ovaries was $29.12 \%$, which equates to the level of intervarietal crossings, but in the process of development, the ovary fell off and the number of ripened hybrid fruits averaged $25.50 \%$.

From the amount of kernels sown, an average of $27.38 \%$ of viable seedlings were grown in combinations, the average productivity of the selected crosses was 7.86 , where the highest crossbreeding rates were found in hybrid combinations of $P$. incisa $\times$ Valery Chkalov-13.56 and in backcrossing (saturating) crossing of this species with cherries $(P$. incisa $\times$ V. Chkalov) $\times$ Krupnoplodnaya -16.40 . 
The aim of this selective work is to determine the genotypes of specific plants (parents or hybrids) as soon as the results become prognostic and, therefore, valuable for selection. Each hybrid family is analyzed separately.

Table 2. Compatibility of cherry varieties $(2 n=2 x=16)$ with distant sour cherry species

\begin{tabular}{|c|c|c|c|c|c|c|c|c|c|c|c|}
\hline \multirow{2}{*}{ 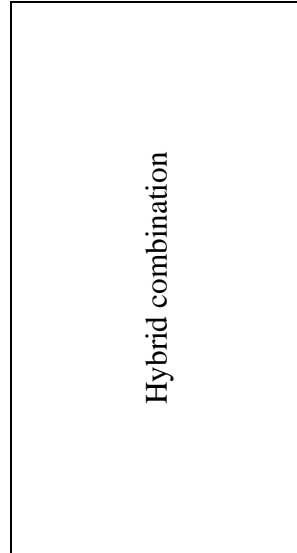 } & \multirow{2}{*}{ 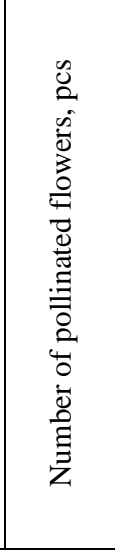 } & \multicolumn{3}{|c|}{$\begin{array}{l}E \\
E \\
\infty \\
0 \\
0 \\
0 \\
0 \\
0 \\
0\end{array}$} & \multicolumn{3}{|c|}{ 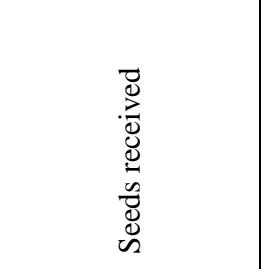 } & \multicolumn{3}{|c|}{ 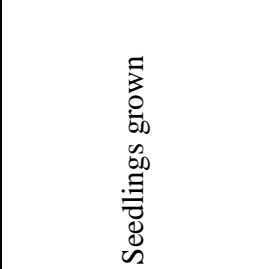 } & \multirow[t]{2}{*}{ 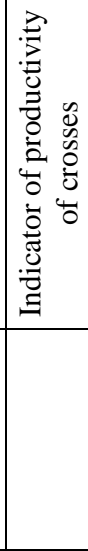 } \\
\hline & & 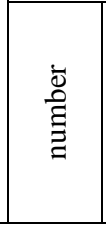 & 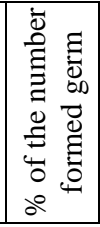 & 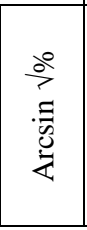 & 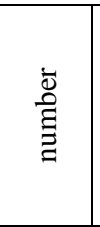 & 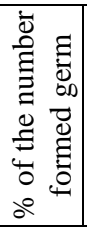 & 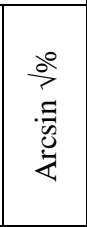 & 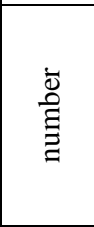 & 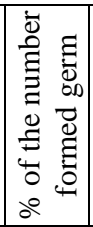 & 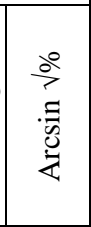 & \\
\hline \multicolumn{12}{|l|}{ Valery Chkalov } \\
\hline P. kurilensis $\times$ & 1758 & 704 & 40,05 & 39,20 & 459 & 26,11 & 30,74 & 87 & 18,95 & 25,82 & 4,94 \\
\hline P. sachalinensis $\times$ & 937 & 307 & 32,76 & 34,81 & 257 & 27,42 & 31,56 & 119 & 46,30 & 42,45 & 12,7 \\
\hline P. pensylvanica $\times$ & 10000 & 350 & 3,50 & 10,66 & 312 & 3,12 & 10,3 & 18 & 5,76 & 13,80 & 0,18 \\
\hline P. incise $\times$ & 2300 & 783 & 34,04 & 35,07 & 680 & 29,56 & 32,94 & 312 & 45,88 & 42,65 & 13,56 \\
\hline $\mathrm{SED}_{05}$ & & & & 6,38 & & & 1,15 & & & 12,94 & \\
\hline \multicolumn{12}{|l|}{ Krupnoplodnaya } \\
\hline P. lannesiana $\times$ & 5000 & 900 & 18,00 & 25,15 & 870 & 17,40 & 24,64 & 54 & 6,20 & 14,11 & 1,08 \\
\hline P. serrullata $\times$ & 12500 & 2700 & 21,60 & 27,62 & 2650 & 21,20 & 28,91 & 876 & 33,05 & 35,07 & 7,00 \\
\hline $\begin{array}{l}(P . \text { incise } \times \\
\text { V. Chkalov })\end{array}$ & 2200 & 1200 & 54,54 & 47,58 & 1097 & 49,86 & 44,36 & 361 & 32,90 & 35,03 & 16,40 \\
\hline $\begin{array}{l}(P . \text { lannesiana } \times \\
\text { Kupnoplodnaya }) \times\end{array}$ & 340 & 115 & 33,82 & 35,77 & 113 & 33,23 & 35,23 & 24 & 21,23 & 24,93 & 7,05 \\
\hline $\begin{array}{l}(P . \text { serrullata } \times \\
\text { Kupnoplodnaya) } \mathrm{x}\end{array}$ & 970 & 231 & 23,81 & 29,20 & 210 & 21,64 & 27,65 & 76 & 36,19 & 36,95 & 7,83 \\
\hline $\mathrm{SED}_{05}$ & & & & 4,37 & & & 8,17 & & & 9,52 & \\
\hline All combinations & $\sum 36005$ & $\sum 7290$ & $\chi 29,12$ & \begin{tabular}{c|}
$\chi \chi$ \\
32,60 \\
\end{tabular} & $\sum 6648$ & $\begin{array}{c}\chi \\
25,50 \\
\end{array}$ & $\begin{array}{c}\chi \\
30,54 \\
\end{array}$ & $\sum 1927$ & $\begin{array}{c}\chi \\
27,38\end{array}$ & $\begin{array}{c}\chi \\
31,59\end{array}$ & $\chi 7,86$ \\
\hline $\begin{array}{l}\text { All hybrid } \\
\text { combinations } \\
\text { (partial differences) }\end{array}$ & \multicolumn{4}{|c|}{$\mathrm{SED}_{05}=5,38 \mathrm{~h}_{2}=22,33 \%$} & \multicolumn{3}{|c|}{$\begin{array}{l}\mathrm{SED}_{05}=4,66 \\
\mathrm{~h}^{2}=53,59 \%\end{array}$} & \multicolumn{3}{|c|}{$\begin{array}{l}\mathrm{SED}_{05}=7,48 \\
\mathrm{~h}^{2}=75,03 \%\end{array}$} & \\
\hline $\begin{array}{l}\text { Depending on from } \\
\text { the paternal form }\end{array}$ & \multicolumn{4}{|c|}{$\mathrm{SED}_{05}=2,69 \mathrm{~h}_{2}=58,07 \%$} & \multicolumn{3}{|c|}{$\begin{array}{l}\mathrm{SED}_{05}=2,33 \\
\mathrm{~h}^{2}=32,62 \%\end{array}$} & \multicolumn{3}{|c|}{$\begin{array}{l}\mathrm{SED}_{05}=3,74 \\
\mathrm{~h}^{2}=13,59 \%\end{array}$} & \\
\hline
\end{tabular}

For the sustainability of fruitage and the formation of high productivity of cherry varieties in the conditions of the south of Russia, it is extremely essential to indicate the transition to a period of deep dormancy and its release. The longer the dormant period, the higher the resistance of plants to frost at the end of winter [16, 17].

In the years of research, depending on the time of occurrence of the main phenological phases of seasonal development, the hybrid genotypes showed considerable differences and variability in the time of release from deep dormancy of flower buds (Table 3). This depends on the weather conditions existing in the autumn-winter period, but despite the conditions of the year, the sequence of output of various hybrids was preserved over the years. 
The adaptability of the varieties received for cultivation in the conditions of the south of Russia should be connected with obtaining forms with a long, long period of deep rest, while combining high winter hardiness, stability to biotic and abiotic environmental factors.

The weather conditions of the autumn-winter period of 2015-2020, with provocative high temperatures in December and January, helped to early release from the dormancy.

Table 3. Duration of the winter dormant period in interspecific hybrids.

\begin{tabular}{|c|c|c|c|c|c|c|}
\hline \multirow{2}{*}{ Hybrid combination } & \multirow{2}{*}{$\begin{array}{l}\text { Number } \\
\text { of seeds, } \\
\text { pcs }\end{array}$} & \multicolumn{5}{|c|}{ Exit of dormant period, $\%$} \\
\hline & & q form & $\hat{o}$ form & early & middle & late \\
\hline P. kurilensis $\times$ P. avium & 87 & middle & middle & 16,1 & 83,9 & 0 \\
\hline$P$. sachalinensis $\times P$. avium & 119 & early & middle & 73,9 & 26,1 & 0 \\
\hline$P$. pensylvanica $\times P$. avium & 18 & late & middle & 11,1 & 50,0 & 38,9 \\
\hline $\begin{array}{l}(P . \text { incisa } \times P . \text { avium }) \times \\
(P . \text { fruticosa } \times P . \text { lannesiana })\end{array}$ & 61 & middle & middle & 73,8 & 24,6 & 1,6 \\
\hline$P$. incisa $\times P$. avium & 312 & middle & middle & 64,7 & 35,3 & 0 \\
\hline P. lannesiana $\times$ P. avium & 54 & early & middle & 75,9 & 24,1 & 0 \\
\hline$P$. serrullata $\times P$. avium & 876 & early & middle & 83,4 & 16,6 & 0 \\
\hline $\begin{array}{l}(P . \text { lannesiana } \times P . \text { avium }) \times \\
\text { Krupnoplodnaya }\end{array}$ & 24 & middle & middle & 83,3 & 12,5 & 4,2 \\
\hline $\begin{array}{l}(P . \text { incisa } \times P . \text { avium }) \times \\
\text { Krupnoplodnaya }\end{array}$ & 361 & middle & middle & 54,0 & 43,2 & 2,8 \\
\hline $\begin{array}{l}(P . \text { serrullata } \times P \text {. avium }) \times \\
\text { Krupnoplodnaya }\end{array}$ & 76 & early & middle & 80,3 & 18,4 & 1,3 \\
\hline P. fruticosa $\times P$. canescens & 54 & late & early & 5,6 & 25,9 & 68,5 \\
\hline P. fruticosa $\times$ P. serrullata & 38 & late & early & 78,9 & 13,2 & 7,9 \\
\hline
\end{tabular}

For growing conditions in regions with short winters (California, North Africa), genotypes with a short dormancy period are needed. The sources of this trait in the station's gene pool are the following species $P$. sachalinensis, $P$. lannesiana, $P$. serrullata, $P$. pseudocerasus and $P$. canescens. Their use in the selection of cherries enables us to obtain hybrids that inherit a short dormant period: in $74 \%$ with the species $P$. sachalinensis, $79 \%$ - P. lannesiana in the first generation and $84 \%$ in backcrossing with cherries, $84 \%$ with the species $P$. serrullata in the first generation and $80 \%$ in the second. The sources of a long dormant period among the studied species of sour cherries were $P$. pensylvanica and $P$. fruticosa. In the progeny of the hybrid combination with the participation of the species $P$. pensylvanica and the cherry variety Valery Chkalov, $27 \%$ of the seeds of pollinated flowers were received; $5.8 \%$ of them sprouted and 18 hybrid seedlings were grown.

From these, only two forms ended deep dormant period at an early date. $50 \%$ of seedlings have a long deep dormant period at the level of the male parent. Seven specimens over a number of years of study completed the rest later than the male parent and were at the level of the species $P$. pensylvanica. Crossbred species $P$. fruticosa with $P$. serrullata and $P$. canescens in their progeny, inherit a long dormant period as well.

Frost resistance and winter hardiness of the plant define the area of its dissemination and the selection value for the climate of Russia. Getting a guaranteed fruit yield is closely related to the adaptive properties of the variety. In the conditions of the North Caucasus, abiotic stresses are especially harmful. In winter - low temperatures and thaws, in springrecurrent frosts, which mainly define the impossibility of showing potential yielding [4].

In winter, frosts in the south of Russia often cause freezing of flower buds. The winter hardiness of the tree does not always coincide with the winter hardiness of the buds. The most significant damage to the cherry flower buds from recurrent frosts happens after dormant release (mid - January-early February). Such affects were found in the resulting 
hybrids and parent forms in the spring of 2014, 2015 and 2020, as well as in the winter of 2019. Thus, increasing the frost resistance of flower buds in this period is the main challenge for increasing the winter hardiness of this crop, in particular, the generative organs of cherry plants (Table 4).

Table 4. Winter hardiness of hybrid seedlings (2014-2020)

\begin{tabular}{|c|c|c|c|c|c|c|c|c|}
\hline \multirow{3}{*}{$\begin{array}{c}\text { Hybrid } \\
\text { combination }\end{array}$} & \multirow{3}{*}{$\begin{array}{l}\text { Number } \\
\text { of seeds, } \\
\text { pcs }\end{array}$} & \multicolumn{3}{|c|}{ Freezing flowering fidney*** } & \multicolumn{4}{|c|}{ Authenticity } \\
\hline & & \multirow{2}{*}{$\begin{array}{c} \\
\text { Min-max } \\
\text { middle score }\end{array}$} & \multicolumn{2}{|c|}{\begin{tabular}{|c|} 
Difference \\
compared to parent \\
forms
\end{tabular}} & \multicolumn{2}{|c|}{ SED } & \multirow[t]{2}{*}{$\mathrm{m} \chi$} & \multirow[t]{2}{*}{$\mathrm{m} \chi \%$} \\
\hline & & & $\begin{array}{cc}\text { maternal } \\
\chi & \chi_{1}\end{array}$ & \begin{tabular}{|cc|}
\multicolumn{2}{|c|}{ Paternal } \\
$\chi$ & $\chi_{2}$
\end{tabular} & 05 & 01 & & \\
\hline $\begin{array}{l}\text { P. kurilensis } \times \\
\text { P. avium }\end{array}$ & 87 & $\frac{0,32-0,81}{0,60}$ & $+0,31$ & $-2,48$ & 0,50 & 0,53 & 0,29 & 12,3 \\
\hline $\begin{array}{l}\text { P. sachalinensis } \\
\times \text { P. avium }\end{array}$ & 119 & $\frac{1,94-3,47}{2,70}$ & $+2,01$ & $-0,34$ & 1,17 & 1,93 & 0,14 & 7,3 \\
\hline $\begin{array}{l}\text { P. pensylvanica } \\
\times \text { P. avium }\end{array}$ & 18 & $\frac{0,52-1,37}{0,95}$ & $+0,95$ & $-2,05$ & 0,67 & 0,81 & 0,18 & 9,1 \\
\hline $\begin{array}{l}P . \text { incisa } \times \\
P . \text { avium } \times \\
(P . \text { fruticosa } \times \\
P . \text { lannesiana })\end{array}$ & 61 & $\frac{1,70-4,30}{3,00}$ & - & - & - & - & - & - \\
\hline $\begin{array}{l}\text { P. incise } \times \\
\text { P. avium }\end{array}$ & 312 & $\frac{0,67-1,71}{1,20}$ & $+1,20$ & $-1,80$ & 0,94 & 1,12 & 0,04 & 18,8 \\
\hline $\begin{array}{l}\text { P. lannesiana } \times \\
\text { P. avium }\end{array}$ & 54 & $\frac{3,12-4,31}{3,75}$ & $+3,15$ & $+0,75$ & 1,75 & 2,05 & 0,34 & 7,8 \\
\hline $\begin{array}{l}P . \text { serrullata } \times \\
P . \text { avium }\end{array}$ & 876 & $\frac{4,80-5,0}{4,90}$ & $+4,73$ & $+1,90$ & 2,37 & 2,50 & 0,29 & 7,3 \\
\hline $\begin{array}{l}\text { (P. lannesiana } \times \\
\text { P. avium }) \times \\
\text { Krupnoplodnaya }\end{array}$ & 24 & $\frac{2,12-2,98}{2,55}$ & $+1,95$ & $-0,45$ & 1,65 & 1,81 & 0,33 & 12,8 \\
\hline $\begin{array}{l}(P . \text { incise } \times \\
P . \text { avium }) \times \\
\text { Krupnoplodnaya }\end{array}$ & 361 & $\frac{0,80-2,40}{1,60}$ & 0 & $-1,40$ & 0,70 & 0,79 & 0,16 & 18,8 \\
\hline $\begin{array}{l}\text { (P. serrullata } \times \\
P . \text { avium }) \times \\
\text { Krupnoplodnaya }\end{array}$ & 76 & $\frac{3,54-4,06}{3,80}$ & $+3,63$ & $+0,50$ & 0,24 & 0,46 & 0,21 & 8,1 \\
\hline $\begin{array}{l}\text { P. fruticosa } \times \\
\text { P.canescens }\end{array}$ & 54 & $\frac{0,08-0,12}{0,10}$ & $+0,10$ & $+0,10$ & 0,02 & 0,12 & 0,04 & 5,8 \\
\hline $\begin{array}{l}\text { P. fruticosa } \times \\
\text { P. serrullata }\end{array}$ & 38 & $\frac{0,63-0,77}{0,70}$ & $+0,70$ & $+0,53$ & 0,11 & 0,20 & 0,28 & 11,3 \\
\hline
\end{tabular}

Footnote: *** from return frosts (-8 C April 2014, -17 C February 2019, -11 C March 2020) m $\chi-$ error of the middle; $\mathrm{m} \chi \%$ - precision of experience

The parent forms and the hybrids derived from their crossing are grown under the same conditions, which made it feasible to assess the transmission of the trait and compare them with each other.

Winter-hardy varieties $P$. kurilensis, $P$. pensylvanica and $P$. incisa when crossing with cherry varieties that are damaged up to 3 points according to the average long-term data, the sign of winter hardiness is transmitted to the progeny in $50 \%$ of hybrid forms.

The findings of the analysis of the average frost damage index over the years of research permit the selected sources of winter hardiness to be transferred to the category of 
donors. The hybrid forms $P$. sachalinensis $\times P$. avium have a winter hardiness lower than in female parents, but higher than in male ones. Meanwhile, the seedlings of P.serrullata $x$ $P$. avium lose their winter hardiness both in the first generation and in backcrossing. This is due to the early release from the dormant period of these seedlings, inherited from the female parent. In hybrid forms obtained by crossing $(P$. incisa $\times P$. avium $) \times(P$. fruticosa $\times P$. lannesiana) winter hardiness varied from 1.7 to 4.3 points. The evaluation in comparison with the parent forms was not performed. These hybrids are considered as rootstock forms.

\section{Conclusion}

Therefore, saturating crosses with large-fruited cherry varieties do not decrease the percentage of seedlings that inherit the early end of deep dormancy in the female parents of $P$. lannesiana, $P$. serrullata, $P$. sachalinensis, and late, long-lasting $-P$. pensylvanica, P.s. incisa, P. fruticosa.

Using in the selection of cherries as the female parents of the species $P$. sachalinensis, $P$. incisa, $P$. serrullata and hybrids $P$. serrullata with cherry, it is possible to get a high number of seedlings under optimal weather conditions. It is found that the female parents of $P$. kurilensis, $P$. pensylvanica, $P$. serrullata, $P$. lannesiana, $P$. fruticosa transmit a sign of release from dormant period in $75 \%$ of cases. Moreover, they are inherited in backcrossing as well.

Donor signs of winter hardiness were found in the species $P$. pensylvanica, P. fruticosa, $P$. incisa. The weather conditions of a number of years enabled us to explore the resulting hybrids on this basis in comparison with the female parents growing in the same conditions. It is found that hybrids with forms of the variety $P$. serrullata lose their winter hardiness, both in the first generation and in satured backcrossing.

These species have been identified and recommended as short-rest donors: P. lannesiana, $P$. serrullata, $P$. sachalinensis, As for late, long-lasting ones: $P$. pensylvanica, $P$. incisa, $P$. fruticosa. The following varieties transmit the sign of winter hardiness to the progeny: $P$. fruticosa, $P$. incisa and $P$. kurilensis.

Acknowledgment. The work was carried out on the VIR plant genetic resources collection within the framework of the state assignment according to the VIR thematic plan on the project No. 06622019-0004 "Collections of vegetatively propagated crops (potatoes, fruit, berry, ornamental, grapes) and their wild VIR relatives - study and rational use".

\section{References}

1. Modern methodological aspects of the organization of the selection process in gardening and winegrowing (Krasnodar, SKZNIISiV, 2012).

2. N. R Hauch, A. F. Iessoni, H. Yamane, and R. Nao, Revisiting the S-allele Nomenclature in Sweet cherry (Prunus avium) using RFLP Profiles, J. Amer. Sec. Hort. Sci., 126 (6) (2001)

3. N. I. Vavilov, Wild relatives of fruit trees in the Asian part of the USSR and the Caucasus and the issue of the origin of fruit trees. Selected works (St. Petersburg, Moscow, 1960).

4. G. V. Eremin, Physiological peculiarities of the development of adaptability, yield and quality of fruits in stone crops in the Foothill zone of the North-West Caucasus (Adygeiskoe republ. kn. izd, Maykop, 2008).

5. Ya. S. Nesterov, Dormant period of fruit crops (Moscow, Selkhozizdat, 1962). 
6. Methods for defining winter hardiness and frost resistance of fruit and berry crops (Michurinsk, 1972).

7. A. M. Fedin, Yu. A. Rogovsky, L. V. Isaeva, Methods of state variety testing of agricultural crops (Moscow, FGBU Gossortkomissiya, 2019).

8. M. M. Tyurina, G. A. Gogoleva, N. V. Efimova and L. K. Goloulina, Resistance determination of fruit and berry crops to cold season stressors in field and controlled conditions (Moscow, 2002).

9. I. M. Ryadnova, G. V. Eremin, Winter hardiness of fruit trees in the south of the USSR (Moscow, Kolos, 1964).

10. L. A. Turovskaya, L. I. Dutova, E. M. Alekhina, Frost resistance of generative buds of stone fruit species in connection with the biological features of their development. Probl. gardening. Sev. Caucasus (Krasnodar, 1970).

11. G.V. Eremin, N. N. Kovalenko, Genetic potential of the Far East in the selection of stone crops in the North Caucasus, Plant gene pool Daln. East. Of Russia: materials of the conference "Results and prospects of the use of worlds. Collections of All-Russian Institute of Plant Genetic Resources named after N. I. Vavilov in the development of the agricultural production of Far East" dedicated. 70th anniversary of the Far East. OS VIR, Vladivostok (1999).

12. N. N. Kovalenko, Sources of selection-valuable traits for distant hybridization of sour cherries. Probl. and prospects are distant. hybridization of fruits. and berries. culture. Abstracts and messages. XX Michurin. readings 25-27 Oct., Michurinsk (2000).

13. G. V. Eremin, I. I. Suprun, Synthesis of complex donors. Modern methodological aspects of the organization of the selection process in gardening and winegrowing (Krasnodar, 2012).

14. G. V. Eremin, Distant hybridization of stone and fruit plants (Moscow, Agropromizdat, 1985).

15. W. L. Howard, An experimental study of the rest period in plants 11 Missouri Agr. Exp. St. Res. Bull. 21 (1915)

16. E. S. Moroz, Experimental and ecological studies of the dormant period of woody plants. Proceedings of V.L. Komarov Botanical Institute of the USSR Academy of Sciences. 5 (1948) 